\title{
El poder del rey ausente: la proclamación de Felipe II en Cuzco en 1557\%
}

\author{
The Power of the Absent King: Felipe II's Proclamation \\ at Cuzco in 1557
}

\section{María Luisa Domínguez-Guerrero \\ Universidad de Sevilla}

En 1557, el cabildo de Cuzco recibió la noticia de la abdicación de Carlos V, así como la orden de reconocer a Felipe II como su nuevo soberano y proclamarlo públicamente. La oligarquía cuzqueña obedeció el mandato y dispuso que se elaborasen dos documentos que certificasen al monarca la lealtad de la ciudad y le informasen de las fastuosas fiestas que habían celebrado en su honor. Con esos documentos analizaremos esta proclamación regia, explicando en qué consistió la ceremonia, cuál fue su significado y quiénes tomaron parte en ella.

Palabras Claves: Proclamación; Fiesta; Felipe II; Cuzco; Siglo XVI.

In 1557, the council of Cuzco was informed of the abdication of Charles V, and they received the order to acknowledge Phillip II as their legitimate sovereign and to proclaim him publicly. This order was soon obeyed by Cuzco's oligarchy, who also instructed the council scribe to write two documents to attest their loyalty to the new king and to inform him of the celebrations in his honor. This paper analyses all the actions which took place within this royal proclamation, explaining how was ceremony, which was its meaning, and who took part therein.

KeYwords: Proclamation; Celebration; Phillip II; Cuzco; XVI ${ }^{\text {th }}$ century.

* Este trabajo ha sido financiado con cargo al Proyecto de Investigación I+D+i del Ministerio de Economía y Competitividad Escritura y ciudad en la Corona de Castilla (siglos XIII-XVII) (HAR2012-32298). 
Es bien sabido cómo en 1556 Carlos I, rey de España y emperador del Sacro Imperio Romano Germánico, enfermo y hastiado tras largos años de luchas y conflictos, decidió abdicar, cediendo la corona de emperador a su hermano Fernando y la de rey de España, Borgoña y las Indias a su hijo Felipe. Una corona, esta última, que podía ceder legítimamente desde hacía apenas un año, desde la muerte de su madre Juana I de Castilla, quien hasta 1555 había sigo la legítima heredera y propietaria de estos territorios, pese a hallarse legalmente incapacitada y apartada del poder. ${ }^{1}$

No fue esta abdicación, sin embargo, un proceso sencillo. Las aspiraciones imperiales de Fernando, aplazadas durante más de treinta años, por fin estaban siendo satisfechas, pero las disputas con su sobrino Felipe por el reparto del poder evidenciaban la fragilidad del gobierno sobre estos vastos y diversos territorios. ${ }^{2}$

El traspaso de poderes, que fue desarrollándose de manera paulatina desde Bruselas, quedó recogido en una ingente cantidad de documentos, elaborados por su secretario Francisco de Eraso, enviados por orden del emperador a todas las instituciones del Imperio, en los que se les notificaba esta abdicación y se les ordenaba que jurasen lealtad a su nuevo soberano.

La mayor parte de estas cartas han desaparecido con el devenir de los siglos pero aun así son muchas las que han llegado hasta nuestros días, ofreciendo una valiosísima información acerca de este momento políticamente tan complejo. En el Archivo Histórico Nacional, en la Sección Nobleza, se encuentra, por ejemplo, la carta que Felipe II envió, ya desde Valladolid, a don Gerónimo Benavides, marqués de Fromistá, exigiéndole juramento de fidelidad. ${ }^{3}$ Asimismo, en el Archivo General de Indias se han conservado numerosos ejemplares de la real cédula, fechada el 16 de enero de 1556, que Carlos I envió a todas las instituciones de gobierno indianas. ${ }^{4}$

1 Rodríguez-Salgado, 1992, 62.

2 Ibidem, 171.

3 Archivo Histórico Nacional (AHN), Frías, 24, 3.

4 Archivo General de Indias (AGI), Indiferente, 427, 30. En los folios 75v-76v está la cédula que se envió al presidente y oidores de la audiencia de Perú (al final de la carta se añade «Despacháronse otras tales cartas para todas las Audiencias de las Yndias»), y en 76v-77v la que se envió al Concejo, Justicias y Autoridades de Lima (al final de la carta se añade «Cartas para todas las cibdades y villas de las Yndias»), en 77v-78v la que se mandó al gobernador y oficiales de Cartagena de Indias (al final indica «Despacháronse otras tales Cartas para todos los gobernadores y ofiçiales de las Yndias»), en 78v-79v la carta al arzobispo de México (que incluye «se despacharon otras tales cartas para los demás arçobispos e obispos de las Yndias e iglesyas catedrales dellas»), y en 82v-83 para el provincial de la orden de San Agustín en Perú (y «Despacháronse deste tenor para todos los provinciales de las Indias de las Ordenes de Santo Domingo e Sant Francisco e Sant Agustín»). 
En estos documentos, además de informar sobre la nueva situación política en la que se encontraba el Imperio, se especificaba de qué manera y a través de qué actuaciones debía llevarse a cabo el reconocimiento de Felipe II como nuevo rey. ${ }^{5}$ Una de estas reales cédulas fue precisamente la que se recibió en 1557 en el cabildo de Cuzco, en Perú, desencadenando toda la serie de hechos y acontecimientos que se desarrollarán a lo largo de estas páginas. ${ }^{6}$

Para una ciudad como Cuzco, separada por miles de kilómetros de la metrópolis, condenada a formar parte de un Imperio a cuyo soberano no vería jamás y a ser gobernada a distancia, bajo la dirección de autoridades delegadas, ${ }^{7}$ la llegada al trono de un nuevo rey no podía suponer una transformación muy directa en su día a día y, sin embargo, la proclamación de este nuevo monarca constituyó uno de los mayores acontecimientos que la ciudad experimentó en esas décadas. ${ }^{8}$

En un Estado monárquico tradicional, el fallecimiento de un rey y el ascenso al trono de su sucesor suponía un evento de enorme importancia para el reino, ya que el poder supremo que el monarca fallecido había ostentado en virtud de los designios divinos debía de pasar a otras manos, también señaladas por Dios mediante la línea sucesoria. ${ }^{9}$ Por este motivo, las proclamaciones reales fueron siempre acompañadas de un complejo ceremonial, en el que se llevaban a cabo toda una serie de rituales establecidos con el fin de legitimar al nuevo monarca ante los ojos de sus súbditos, garantizando así su reconocimiento y aceptación. ${ }^{10}$

En Castilla, estas celebraciones cívicas, en las que tomaban parte todos los estratos sociales de la ciudad, se remontan al menos hasta el siglo $\mathrm{XV}^{11}$ y constituían uno de los acontecimientos de mayor importancia para las villas y ciudades, que ponían en juego todos los recursos de los que disponían, a fin de garantizar que el lujo y la solemnidad de la fiesta reflejase la grandeza del municipio y la lealtad de sus habitantes. ${ }^{12}$

5 De hecho el envío de instrucciones para la realización de una ceremonia de proclamación fue una acción frecuente a lo largo de toda la edad moderna. Marina Barba, 1988, 276.

6 AGI, Lima 110, doc. 21.

7 Sánchez-Arcilla Bernal, 1999, 261.

8 Esta circunstancia puede percibirse con gran claridad en la obra de Esquivel y Navia, 1902, donde se lleva a cabo una pormenorizada exposición de los acontecimientos más importantes acaecidos en Cuzco a lo largo del siglo XVI, extraídos del análisis de los libros de actas del cabildo civil de la ciudad.

9 Marina Barba, 1988, 275.

10 Ibidem, 276.

11 García Bernal, 2006, 233; Val Valdieso, 2006, 379.

12 Asenjo González, 1999, 131. 
Pero si en Castilla las proclamaciones reales constituían un acontecimiento de enorme importancia social y política, mucha más transcendencia alcanzaron en el Nuevo Mundo, principalmente debido a la gran distancia que mediaba entre la metrópolis y sus colonias, que obligaba a emplear todos los recursos disponibles para fortalecer los lazos culturales y políticos que les unían, y mantener así vivo el sentimiento de unidad y de pertenencia a un mismo Imperio. ${ }^{13}$ Por ello, para la etapa borbónica hay constancia de la celebración de estas fiestas en todas las ciudades americanas, tanto grandes como pequeñas, que después eran relatadas y enviadas al monarca como demostración del entusiasmo con el que había sido aclamado. ${ }^{14}$

Estos relatos pormenorizados, cargados de simbolismo y figuras retóricas, serán denominados, ya en el siglo XVII, Relaciones de fiestas, y serán, según sostienen algunos autores, la razón por la cual, tras unos primeros años en los que los festejos adoptaron diferentes formas, pronto comenzó a percibirse una tendencia uniformadora dentro de las manifestaciones públicas de alegría y acatamiento tras el ascenso al trono de un nuevo monarca, dando como resultado que durante los siglos XVII y XVIII estas celebraciones repitiesen una y otra vez los mismos esquemas sin apenas introducir elementos originales. ${ }^{15}$

Y es que a la hora de organizar un festejo de este calibre era frecuente que las autoridades recurriesen al ejemplo de las celebraciones pasadas, de las cuales habría quedado constancia en estas Relaciones, para garantizar que la celebración superase o al menos igualase en esplendor a las anteriores. ${ }^{16}$

Los orígenes de estas Relaciones de fiestas pueden ser hallados en las cartas o epístolas de relación, ${ }^{17}$ documentos públicos o privados que informaban de un acontecimiento a una persona o institución. Ya desde la Baja Edad Media el empleo de crónicas oficiales con fines propagandísticos del monarca se había convertido en una constante. Una de las formas de obtener información para que escritores profesionales hicieran estas crónicas,

13 Rípodas Arranz, 2006, 245.

14 Ibidem, 246.

15 Escalera Pérez, 2002, 318.

16 Valenzuela Márquez, 2001, 273. Cercano al nuestro, por ejemplo, es el caso de la entrada del virrey Francisco de Toledo en Cuzco en 1572. Una vez en la ciudad, los oficiales municipales admitieron poseer narraciones de anteriores entradas de virreyes en Lima y haber pretendido realizar en Cuzco unos festejos que las superasen, para, de esta forma, demostrar la superioridad de su ciudad sobre Lima. Osorio, 2006, 804.

17 Cátedra García, 1996, 35. 
era a través de las cartas que muchos súbditos enviaban con el fin de prestar un servicio y obtener algún beneficio, como el de ver su nombre escrito en la crónica. ${ }^{18}$

Las cartas conteniendo descripciones de fiestas celebradas en el continente americano son relativamente frecuentes a partir del siglo XVII pero para el siglo XVI, en cambio, no hay constancia de que se hayan conservado muchas, lo que convierte a esta que presentamos en un documento poco común. ${ }^{19}$ Como ya se ha indicado, el desencadenante de los acontecimientos que tuvieron lugar en Cuzco fue una real cédula en la que Carlos V informaba de su decisión de ceder el trono a su hijo Felipe y ordenaba a todos sus súbditos que lo reconociesen como su nuevo soberano y que lo proclamasen públicamente en la ciudad llevando a cabo una serie de actos simbólicos: «e ansí os encargamos y mandamos que, alçando pendones y haziendo las otras solenidades que se requieren y acostunbran».

Este documento, fechado en 16 de enero de 1556, fue acompañado por otra real cédula, fechada tan solo un día más tarde, el 17 de enero, en la que Felipe II, intitulándose ya «El Rey», comunica su aceptación del trono y su intención de gobernar el reino con rectitud y justicia, así como la promesa de otorgar mercedes a aquellos que le obedezcan y sirvan fielmente:

acordándome de vuestra fidelidad y lealtad y del amor y afiçión espeçial que entre vosotros he conoçido, mandaré mirar por lo que general y particularmente os tocare, haziéndoos merçed y fauor en lo que justo sea como lo mereçéyes [...]

Estas buenas palabras de agradecimiento hacia sus súbditos no dejan de tener una cierta carga irónica si se tiene en cuenta que apenas diez años antes, en 1545, la fidelidad y lealtad y amor y afiçión especial de los pobladores españoles del Perú hacia su rey, se manifestó a través de una rebelión que había puesto en jaque las instituciones de gobierno en América y desafiado peligrosamente el poder real en Indias. ${ }^{20}$

De acuerdo con el libro de actas del cabildo de la ciudad, estas cartas llegaron a Cuzco el 14 de septiembre de 1556, aunque la noticia se les

18 Ruiz García, 1999, 286.

19 Poco común pero en modo alguno único. Otros ejemplos de cartas en la que se describen fiestas celebradas en Indias en honor de la monarquía pueden hallarse en Gómez Gómez (2009, 461-475), donde se relata la celebración se llevó a cabo en Guadalajara por el nacimiento del príncipe Fernando y la victoria de don Juan de Austria sobre los turcos; o una relación de fiestas celebradas en Cuzco tras la victoria de Lepanto que se transcribe en CODOIN América (24, 169-173), citada por López Cantos, 1992, 26.

20 Parker, 2010, 82. 
había adelantado casi un mes, ya que desde el 23 de agosto de ese año la abdicación del emperador fue un tema recurrente dentro de las reuniones del cabildo. La organización de una fastuosa ceremonia de proclamación se convirtió entonces en objetivo prioritario para los miembros del gobierno local, quienes dedicaron largas horas a definir todos los detalles de la fiesta, desde los estandartes que se mandarían bordar hasta los juegos y diversiones con los que se cerraría la celebración. ${ }^{21}$

En un principio la proclamación quedó fijada para el 1 de noviembre aunque la magnitud de los preparativos forzó su aplazamiento, primero hasta el 30 del mismo mes, día de san Andrés, y finalmente hasta el 8 de diciembre, para dar así más tiempo a los organizadores. Llegado el día, tuvo lugar en Cuzco la proclamación de Felipe II como nuevo rey, de la cual el cabildo puso buen cuidado en dejar constancia escrita para garantizar que la información de su obediencia y lealtad llegara a oídos del monarca.

$\mathrm{Y}$ es que este testimonio, contenido en los documentos que presentamos, no es un simpe relato descriptivo de la fiesta, sino que constituye una expresión directa y oficial del acatamiento de sus súbditos al nuevo monarca. Si en Castilla era común que, tras la proclamación pública del rey, las ciudades enviasen delegados a la corte para prestar juramento de vasallaje y obediencia ante el monarca: ${ }^{22}$ en las Indias, tan alejadas, se conformaban con enviar un documento oficial intitulado por las principales autoridades locales.

En el caso cuzqueño, fueron dos los documentos que se enviaron a la corte tras la proclamación. El primero de ellos es una carta, enviada en nombre de las autoridades civiles de Cuzco y que fue validada mediante la firma del corregidor, Bautista Muñoz, y de varios de los regidores de la ciudad, así como con la suscripción y firma del escribano del cabildo, en cuya oficina de expedición fue elaborado el documento. ${ }^{23}$

En esta carta, fechada el 10 de diciembre de 1557, es decir, casi dos años después de que fuesen enviadas las reales cédulas, la ciudad y sus gobernantes reconocen explícitamente a Felipe II como nuevo soberano y se hace mención a la ceremonia de proclamación a través de la cual se ha llevado a cabo este reconocimiento público. ${ }^{24}$ Sin embargo, este no es el único

21 Esquivel y Navía, 1980, 183.

22 Carrasco Manchado, 2014, 203.

23 Domínguez Guerrero, 2011.

24 Este documento coincide plenamente en forma y contenido con otra carta, escrita en la misma circunstancia, que enviaron desde la ciudad de León de Nicaragua el 17 de febrero de 1558, reconociendo a Felipe II como nuevo rey, haciendo constar la existencia de una ceremonia de proclamación en la ciudad y solicitando mercedes: En lo demás que Vuestra Magestad manda se a cumplido y cum- 
contenido que puede hallarse en el documento ya que, a partir de la mitad aproximadamente, esta carta de acatamiento se convierte en una petición en la que se solicitan algunas mercedes, como que se mantenga en el cargo de virrey del Perú al marqués de Cañete y que se perpetúen las encomiendas de indios, que tras las Leyes Nuevas habían quedado limitadas en el tiempo. ${ }^{25}$

El otro documento que se envió a la corte es un acta donde se certificaba que efectivamente en la ciudad se llevaron a cabo distintos actos de celebración por el ascenso al trono del nuevo rey y se realiza una descripción de cómo se desarrolló la ceremonia de proclamación regia, qué tipo de actos se llevaron a cabo y quiénes participaron en ellos. Este documento se cierra con la validación del escribano del cabildo de Cuzco, Sancho de Orúe, quien mediante su suscripción y signo notarial aporta completa veracidad al contenido de esta acta.

La proclamación de Felipe II en Cuzco comenzó en la Plaza Mayor, centro neurálgico de toda la vida civil de la ciudad, habiéndose levantado previamente en ella un tablado desde el que las autoridades pudiesen llevar a cabo las distintas actuaciones siendo vistos por todos los asistentes. ${ }^{26}$ Sobre este tablado se encontraban situados los retratos del monarca que dejaba de serlo, Carlos V, y el del rey que asumiría su lugar, Felipe II, generando de esta forma un vínculo legitimador que enlazaba las dos figuras regias atribuyéndoles una pátina de continuidad. ${ }^{27}$ Sobre esta tarima se encontraban también las dos máximas autoridades de la ciudad representando al poder civil y al eclesiástico: el corregidor, Juan Bautista Muñoz, y el obispo, don Juan Solano, ambos vestidos con sus mejores galas.

El documento, tal y como ocurría en general en las Relaciones de fiestas ${ }^{28}$ hace mucho hincapié en las suntuosas vestimentas y en el lujo que ostentaban los protagonistas de la fiesta. Se habla de tejidos, de colores, de

plirá a la letra y se alçaron pendones en esta çiudad y en la de Granada en nombre de toda la prouinçia e se hizieron las otras solenidades neçesarias [...] plegue a nuestro Señor de graçia para que la voluntad y real desseo de Vuestra Magestad se effectue, que será dar fin a muchas buenas obras començadas y emprender otras muchas y muy grandes. AGI, Guatemala 43, 11.

25 Vaca de Osma, 1998, 308.

26 Esta plaza, heredera de la antigua Huacaypata o plaza cívico-religiosa incaica, fue escenario de todos los grandes acontecimientos, tanto lúdicos como dramáticos, que tuvieron lugar en Cuzco durante el siglo XVI. En ella se celebraron fiestas civiles y religiosas, se leyeron los pregones, se presentaron las nuevas autoridades, y fueron ejecutados Diego de Almagro en 1538, tras la guerra civil, y Túpac Amaru, en 1572, tras el levantamiento indígena. Vid. Larraín Valdés, 1996, 359; VV.AA, 2000, 86; Sanz Camañes, 2004, 63; Pérgolis, 2002, 91.

27 Para saber más sobre el empleo de retratos regios en las proclamaciones reales ver Mínguez Cornelles, 1995.

28 García Bernal, 2009, 356; Marina Barba, 1988, 278. 
adornos y joyas con gran detenimiento, en un intento de dejar clara constancia de su presencia, ya que esta riqueza en el vestir era sinónimo de superioridad social y de prestigio y como tal debía ser puesta de manifiesto.

La ceremonia se inició con el alzamiento de los dos pendones, el estandarte regio, que por ser el más importante era llevado por el corregidor, como máxima figura de autoridad y representante directo del poder del monarca, ${ }^{29}$ y el estandarte con el escudo de la ciudad y la imagen del apóstol Santiago, ${ }^{30}$ portado por el regidor más antiguo, que era el miembro del gobierno civil que seguía en importancia al corregidor. Mediante este acto de alzar los pendones, que fue llevado a cabo acompañado de música, se realizaba la aclamación del nuevo monarca, representado simbólicamente por su pendón, constituyéndose como una materialización de la esencia del poder regio. ${ }^{31}$

El siguiente paso en esta ceremonia de proclamación se focalizó en torno a otro elemento que poseía el poder simbólico de representar al soberano en la distancia: el documento escrito. ${ }^{32}$ La lectura de la real cédula mediante la que Carlos I notificaba su abdicación y, posteriormente, la de la cédula de Felipe II en la que informaba de su ascenso al trono se constituye como uno de los actos centrales de la ceremonia, en el que el documento pasaba a ser el núcleo de toda la acción y en torno a quien se agrupaban las miradas y las acciones. ${ }^{33}$

De esta forma, el documento, firmado por la propia mano del rey, se eleva a una categoría simbólica muy superior a la de otros elementos relacionados con la monarquía, ya que se identifica con la figura regia en sí, representando en la distancia al propio monarca como una materialización de la palabra y la voluntad del soberano. ${ }^{34}$ Por esta razón, el documento recibirá grandes muestras de respeto y devoción, como son el beso que aquellos que lo tocan le dan, y el gesto de ponerlo sobre sus cabezas en señal de sumisión. ${ }^{35}$

29 Sobre el estandarte regio, sus orígenes y simbología véase Cárdenas Gutiérrez, 2002, 200.

30 Acerca de la presencia del apóstol en la proclamación regia Valenzuela Márquez (2001, 125) dice: «El apóstol Santiago era, y no por azar, el santo protector de los conquistadores. Santiago era el símbolo del impulso y del coraje cristianos, ya fuese bajo su representación de mata-moros como de mata-indios. Su imagen de caballero sosteniendo el estandarte de la fe constituirá una figura persistente en el imaginario de la expansión imperial por América».

31 Valenzuela Márquez, 1999, 424.

32 Romero Tallafigo, 2000, 178.

33 Sobre el lenguaje del poder real véase Ruiz García, 1999, 281.

34 Bouza Álvarez, 1998, 6.

35 Acerca de las muestras de respeto realizadas hacia los documentos regios véase Romero Tallafigo, 2009, 448. 
Este fenómeno de la personificación de un objeto inanimado, elevándolo además a una categoría casi mayestática, resultaba de vital importancia en el caso indiano, ya que para mantener el control sobre un territorio tan extenso, incluso en la distancia, era imprescindible emplear mecanismos de control político, pero no menos importante era obtener lo que distintos autores han denominado «la dominación simbólica», basada en ritos y prácticas que traían consigo un contenido ideológico legitimador. ${ }^{36}$

Para enfatizar el poder representativo del documento, su lectura se lleva a cabo en un lugar público y ante un amplio número de oyentes, entre los que se destacan, por el lujo que ostentan y la posición privilegiada que ocupan, los miembros de la oligarquía urbana y los representantes del poder, a quienes su proximidad al documento les permitirá compartir parte de su carga simbólica y legitimadora, ${ }^{37}$ especialmente al corregidor, quien al realizar la lectura en voz alta se convierte automáticamente en canalizador del poder regio contenido en las reales cédulas. ${ }^{38}$

Una vez leídos los documentos, la máxima autoridad de la ciudad, el corregidor, actuando en representación del conjunto de los ciudadanos, reconoció al nuevo monarca de forma pública y patente, gritándolo a altas vozes para que todos lo escuchasen, y también de manera oficial, pidiendo al escribano del cabildo que certificase este reconocimiento mediante un documento oficial y público, que será precisamente este acta que después se envió a la corte acompañando a la otra carta para servir como prueba fehaciente del entusiasmo con el que sus súbditos habían aceptado a su nuevo monarca y la magnitud de los festejos que se habían llevado a cabo en su honor. Tras el corregidor, el resto de las autoridades de la ciudad repetirán su actuación y reconocerán de forma pública a Felipe II como soberano.

A continuación, estando todavía los asistentes al acto reunidos en torno a la tarima sobre la que se estaba desarrollando la ceremonia, se procedió a llevar a cabo el rito de derramar monedas de oro y plata entre el público. Este acto, protagonizado por las dos principales figuras públicas de la ciudad, el corregidor y el obispo, hunde sus raíces en la tradición romana, aunque no se constituyó como una parte habitual de las ceremonias de proclamación en Castilla y en Indias hasta precisamente el ascenso al trono de Felipe II. ${ }^{39}$ Mediante este rito se lograba que la imagen de la ceremonia que-

36 Valenzuela, 2001, 29.

37 Castillo Gómez, 1998, 478.

38 Ruiz García, 1999, 281.

39 Vilaplana Persiva, 1997, 183. 
dase más profundamente grabada en los asistentes, que podrían conservar un recuerdo material del acto, y además el hecho de entregar oro sería percibido como una muestra de magnificencia y generosidad del nuevo monarca.

Con el ritual del reparto de medallas conmemorativas finalizaba la parte que podría denominarse «estática» de la ceremonia de proclamación, dejando paso a la parte más dinámica en la que las actuaciones ya no se sucedían en torno a un único espacio central, el tablado, sino que se extendían por distintos puntos de la ciudad.

Tras abandonar la plaza pública, el corregidor, portando aún el estandarte regio, y la multitud que se agrupaba en torno al tablado central fueron recorriendo la ciudad repitiendo el mismo grito: Castilla, Castilla; Cuzco, Cuzco; Perú, Perú, por el Rey don Felipe, nuestro señor, llevando así a cabo un ritual que fue muy habitual en las ceremonias de proclamación tanto en Castilla ${ }^{40}$ como en Indias ${ }^{41}$ en el que algunos expertos han querido ver una representación simbólica del acto de toma de posesión de la ciudad por parte del monarca, ${ }^{42}$ ya que el pueblo, al repetir estos gritos, no hacía sino confirmar la presencia regia en todos los rincones de la villa.

Un ritual muy similar a este era el que se llevaba a cabo durante las entradas de los nuevos virreyes del Perú en las ciudades bajo su gobierno. Los virreyes, representantes directos del monarca en el Nuevo Mundo, también peregrinaban por las ciudades como símbolo de posesión de estos territorios. ${ }^{43}$

Junto a la aclamación regia, la música ocupó un lugar muy destacado en esta parte de la celebración. Este elemento artístico fue y sería durante los siglos posteriores, uno de los puntos clave dentro de las proclamaciones, ya que no solo amenizaba la fiesta y servía como foco de atracción para los asistentes a la ceremonia, sino que también servía como un vehículo de trasmisión de mensajes ideológicos que reforzaban el poder regio. ${ }^{44}$

Los atabales y las trompetas acompañaron a los estandartes en su recorrido por la ciudad, y las canciones, especialmente compuestas para la ocasión, cerraron este acto. Por la narración realizada por el escribano sabemos que estos «motes y coplas» trataban sobre la alegría de los súbditos ante el ascenso al trono de su nuevo soberano, pero por desgracia no se

\footnotetext{
40 Marina Barba, 1988, 278.

41 Valenzuela Márquez, 2001.

42 García Bernal, 2006, 234.

43 Osorio, 2006, 790.

44 Torre Molina, 2004, 349
} 
ha conservado una transcripción de las letras completas, sino tan solo del estribillo que compartían todas las canciones, y que decía: Venga en hora buena, en hora buena venga, el rey don Felipe, a la nueva tierra.

Una vez finalizada la proclamación civil de Felipe II, dio comienzo la ceremonia religiosa, que tuvo lugar, como no podía ser de otra forma, en la principal iglesia de la ciudad: la catedral de Cuzco, que en estos años aún no se localizaba en el magnífico edificio que en 1560 se comenzaría a construir para ella, sino que estaba situada en el antiguo palacio del Inca Viracocha. ${ }^{45}$

Durante la misa, el papel protagónico de la ceremonia, que hasta el momento había permanecido en manos del poder civil, queda traspasado a la autoridad religiosa, representada por su principal exponente: el obispo de la ciudad. Así, de la misma forma que el corregidor había encabezado la procesión laica que recorrió la ciudad aclamando al monarca por sus calles, el obispo entró en la catedral acompañado por un séquito de religiosos de las distintas órdenes presentes en la ciudad: franciscanos, dominicos y mercedarios.

En este punto, el hilo narrativo del documento se detiene y el relato de la celebración da paso a un contenido más solemne, procediéndose a incluir un reconocimiento expreso del nuevo monarca y un juramento de obediencia y sumisión por parte de las autoridades tanto civiles como religiosas de la ciudad, así como de los habitantes de la villa en general. Para certificar la veracidad de este juramento, el documento incluye una medida de validación exclusivamente para él, en forma de relación de testigos, en la que aparecen nombrados cinco de los regidores de la ciudad y se hace mención además al resto de testigos que presenciaron el acto, que fueron muchos vecinos y estantes en esta ciudad.

De esta forma concluyó la ceremonia de proclamación real propiamente dicha y, una vez reconocido el nuevo monarca, se procedió a llevar a cabo una serie de actos lúdicos y juegos celebrados en su honor en los que tomaron parte el conjunto de los habitantes de la ciudad. Este contenido festivo era un elemento de gran importancia dentro del complejo ceremonial que se desarrollaba en las ciudades durante las ceremonias de proclamación, ya que servía para fijar la celebración en el recuerdo de los súbditos, y al mismo tiempo, para reafirmar el contenido legitimador. ${ }^{46}$

45 Bauer, 2004,124.

46 Valenzuela Márquez. 2001, 31. 
En Cuzco estos festejos estuvieron compuestos por luminarias, corridas de toros y un juego de cañas, ${ }^{47}$ es decir, exactamente los mismos elementos que podían encontrarse en cualquier celebración cívica castellana en estas fechas ${ }^{48}$ Estas diversiones se encuadran en lo que se denominarían fiestas caballerescas, que se encontraban es esos momentos en su época de máximo esplendor. ${ }^{49}$

Los toros, por ejemplo, eran un referente en todo tipo de festejos y celebraciones tanto civiles como religiosas en Castilla, como se colige de la continua mención que se hace de ellos en casi todas las descripciones de fiestas que se elaboraron en estos años. ${ }^{50}$ Para el caso indiano, existe constancia de fiestas taurinas desde apenas unos años después de la llegada de los españoles al Nuevo Mundo, apareciendo en los documentos numerosas menciones a esta actividad, en la que participaban tanto españoles como nativos. ${ }^{51}$ Sin embargo, menos de diez años después de los acontecimientos que se describen en esta narración, los juegos con toros fueron prohibidos por Pío V mediante una bula papal, ${ }^{52}$ permaneciendo así hasta que, en 1596, Clemente VIII levantó esta prohibición.

En Cuzco, la proclamación de Felipe II fue celebrada con treinta toros, un número nada despreciable, especialmente teniendo en cuenta que la presencia de estos animales en América solo databa de unas décadas antes. ${ }^{53}$ De estos toros, el documento indica que fueron «traídos y corridos» en la Plaza Mayor de la ciudad, aunque no se especifica quiénes fueron los protagonistas directos de esta parte de la fiesta.

Por su parte, los juegos de cañas eran un remedo de los tradicionales combates caballerescos medievales que en el caso americano contaban con la diferencia de estar protagonizados, en lugar de por la nobleza, que era prácticamente inexistente en Indias en estos años, por las principales figuras civiles de la ciudad, regidores, cabildantes y miembros de la oligarquía urbana, todos vestidos con sus mejores galas. ${ }^{54}$

47 Fernández Fuster, 2005.

48 Asenjo González, 1999, 132; García Bernal, 2009, 353, 359.

49 García Bernal, 2009, 349.

50 García Bernal, 2006, 206.

51 Castillo Martos, 2003. 217-222. Por ejemplo, se sabe que en la villa de Potosí se corrieron toros en 1556 para celebrar la coronación de Felipe II.

52 Pío V, De Salutis Gregis Dominici, 1567. Ver Vincent, 2003, 342.

53 López Cantos, 1992, 159.

54 Ibidem, 174-175. 
Si respecto a la corrida de toros el documento no se detiene a indicar quiénes participaron en ella, en el caso del juego de cañas el acta se explaya en la enumeración de todos los personajes que tomaron parte en la actividad, incluyendo no solo a los que verdaderamente jugaron sino también a aquellos a quienes por su posición social les habría correspondido combatir pero por distintas situaciones personales - luto, enfermedad, etc.habían tenido que ser sustituidos por otra persona. Esto implicaría que la participación en los juegos de cañas era considerada un símbolo de honor, por lo que incluso los que no pudieron jugar dejan constancia de que por su jerarquía les habría correspondido hacerlo.

De entre todos los nombres de miembros de la oligarquía cuzqueña que se incluyen no podemos evitar destacar dos, uno es el del joven Gómez Suárez de Figueroa, hijo mestizo de un español, que pocos años más tarde alcanzaría gran fama como escritor y cronista bajo el nombre del Inca Garcilaso de la Vega; el otro es el de don Carlos Yupangui, de quien se dice que era indio, lo que implicaría la presencia no solo de mestizos, como Gómez Suárez, sino también de un nativo dentro del exclusivo círculo de la oligarquía cuzqueña. ${ }^{55}$

Con esta información y la validación del escribano del cabildo se cierra este documento, que, junto con la carta del cabildo, fue posteriormente enviado a la corte y allí conservado, cerrando de esta manera el proceso comunicativo que se había iniciado dos años antes con la redacción y envío desde Bruselas de las dos reales cédulas de Carlos V y Felipe II.

De la lectura de estos documentos no puede dejar de extraerse una reflexión acerca de la trascendental importancia que la palabra escrita alcanzó en este periodo, sirviendo no solo como un vehículo de trasmisión de información administrativa entre instituciones que se encontraban alejadas, sino como un nexo de unión simbólica entre el señor natural y los territorios bajo su dominio, físicamente separados por una distancia insalvable pero estrechamente conectados por unos lazos de poder y sumisión que viajaban dentro de estos documentos bajo la forma de símbolos, imágenes figuradas y palabras ceremoniosas.

Recibido el 16 de enero de 2014

Aceptado el 4 de marzo de 2015

55 Sobre la composición étnica de las oligarquías en las ciudades del virreinato del Perú puede consultarse Lockhart, 1968. 


\section{MARÍA LUISA DOMÍNGUEZ-GUERRERO}

\section{Bibliografía}

Asenjo González, María: «Las ciudades», en Nieto Soria, José Manuel (dir.), Orígenes de la Monarquía hispánica: propaganda y legitimación (14001520), Madrid, Dykinson, 1999, 105-140.

Bauer, Brian S.: Ancient Cuzco. Heartland of the Inca, Austin, University of Texas Press, 2004.

Bouza Álvarez, Fernando: Imagen y propaganda: capítulos de historia cultural del reinado de Felipe II, Madrid, Akal, 1998.

Cárdenas Gutiérrez, Salvador: «Las insignias del rey: disciplina y ritual público en la ciudad de México», Jahrbuch für Geschichte Lateinamerikas, 39, Viena, 2002, 193-216.

Carrasco Manchado, Ana Isabel: «Las entradas reales en la Corona de Castilla: pacto y diálogo político en torno a la apropiación simbólica del espacio urbano», en Boucheron, Patrick y Genet, Jean-Philippe (eds.), Marquer la ville. Signes, traces, empreintes du pouvoir (XIIIe-XVIe siecle), París, La Sorbonne, 2014, 191-234.

Castillo Gómez, Antonio: «Del odio a la vista: Espacios y formas de la publicidad del escrito (siglos XV-XVI)», en Soto Rábanos, José M. ${ }^{a}$ (coord.), Pensamiento medieval hispano. Homenaje a Horacio Santiago-Otero, Madrid, Editorial CSIC, 1998, 473-497.

Castillo Gómez, Antonio: «Del tratado a la práctica. La escritura epistolar en los siglos XVI y XVII», en Sáez, Carlos y Castillo, Antonio (eds.), La correspondencia en la historia. Modelos y prácticas de la escritura epistolar. Actas del VI congreso internacional de historia de la cultura escrita, Madrid, Calambur, 2002, 79-108.

Castillo Martos, Manuel: «Toros en el Altiplano Andino (1550-1650). Una aproximación a su historia», García-Baquero González, Antonio y Romero de Solís, Pedro (coords.), Fiestas de toros y sociedad, Universidad de Sevilla, Secretariado de Publicaciones, 2003, 211-234.

Castro, Bartolomé: «El poder y lo simbólico», Brocar: Cuadernos de investigación histórica, 23, La Rioja, 1999, 229-254.

Cátedra García, Pedro Manuel: «En los orígenes de las “epístolas de relación”», en García de Enterría, M. ${ }^{a}$ Cruz; Redondo, Agustín; Ettinghausen, Henry; Infantes, Víctor (eds.), Las relaciones de sucesos en España (1500-1750), París/Alcalá de Henares, La Sorbonne/Universidad de Alcalá, 1996, 33-64.

Domínguez Guerrero, María Luisa: «La escribanía del cabildo de Cuzco (15341699)», Historia. Instituciones. Documentos, 38, Sevilla, 2011, 67-110.

Escalera Pérez, Reyes: «Del esplendor al ocaso: la simbología política en la fiesta en Málaga y Granada, de Felipe V a Isabel», en Pérez Martínez, Herón y Skinfill Nogal, Bárbara (eds.), Esplendor y ocaso de la cultura simbólica, México, El Colegio de Michoacán, 2002, 317-342. 
Esquivel y Navia, Diego: Noticias cronológicas de la gran ciudad del Cuzco, edición de Félix Denegrí Luna, Lima, Fundación Augusto N. Wiese, 1980.

Fernández Fuster, Juan Manuel y Fernández Truan, Juan Carlos: «Génesis de los juegos de cañas como juegos de combate», ponencia presentada al X Congreso Internacional de Historia del Deporte, Sevilla, noviembre de 2005. Disponible en: http://www.cafyd.com/HistDeporte/htm/pdf/3-5.pdf

García Bernal, José Jaime: «El fasto público y el orden comunicativo de la España moderna», Garrido Aranda, Antonio (coord.), El mundo festivo en España y América, Córdoba, Universidad de Córdoba, Servicio de Publicaciones, 2005, 77-90.

García Bernal, José Jaime: El fasto público en la España de los Austrias, Sevilla, Universidad de Sevilla, Secretariado de Publicaciones, 2006.

García Bernal, José Jaime: «Triunfos reales y teatros funerarios: del ritual ciudadano al salón cortesano (siglos XVI-XVIII)», Fiesta y simulacro: Palacio Episcopal de Málaga, 19 de septiembre-30 de diciembre 2007, Sevilla, Consejería de Cultura, 2007, 64-83.

García Bernal, José Jaime: «La oligarquía sevillana y las fiestas caballerescas en el ápice del imperio filipino (1571-1584)», en Álvarez Santaló, León Carlos (coord.), Estudios de historia moderna en homenaje al profesor Antonio García-Baquero, Sevilla, Universidad de Sevilla, Secretariado de Publicaciones, 2009, 349-364.

García Bernal, José Jaime: «Memoria funeral de los Austrias. El discurso histórico y las noticias políticas en las exequias sevillanas de los siglos XVI y XVII», en De Jonge, Krista; García García, Bernardo José y Esteban Estríngana, Alicia (coords.), El legado de Borgoña. Fiesta y ceremonia cortesana en la Europa de los Austrias (1454-1648), Madrid, Fundación Carlos Amberes/Marcial Pons, 2010, 673-704.

Gómez Gómez, Margarita: «La ciudad como emblema: ceremonias de recepción del Sello Real en Indias», García Bernal, Manuela Cristina y Olivero Guidobono, Sandra (coords.), El municipio indiano: relaciones interétnicas, económicas y sociales: Homenaje a Luis Navarro García, Sevilla, Universidad de Sevilla, Servicio de Publicaciones, 2009, 461-475.

Larraín Valdés, Gerardo: Diego de Almagro: Biografía, Buenos Aires, Editorial Luxemburgo, 1996.

Lockhart, James: Spanish Peru (1532-1560). A social study, Wisconsin, University of Wisconsin Press, 1968.

López Cantos, Ángel: Juegos, fiestas y diversiones en la América española, Madrid, Mapfre, 1992.

Marina Barba, Jesús: «La relación Monarquía-ciudad en el mecanismo sucesorio. Proclamación y honras fúnebres de Felipe V en Ciudad Real», Cuadernos de Estudios Manchegos, 18, Ciudad Real, 1988, 275-289. 


\section{MARÍA LUISA DOMÍNGUEZ-GUERRERO}

Mínguez Cornelles, Víctor: Los reyes distantes: imágenes de poder en el México virreinal, Castellón, Diputación de Castellón, 1995.

Osorio, Alejandra: «La entrada del virrey y el ejercicio de poder en la Lima del siglo XVII», Historia Mexicana, LV, 3, 2006, 767-831.

Parker, Geoffrey: Felipe II. La biografía definitiva, Barcelona, Planeta, 2010.

Pérgolis, Juan Carlos: La plaza: el centro de la ciudad, Bogotá, Universidad Nacional de Colombia, 2002.

Rípodas Arranz, Daisy: «Versión de la monarquía de derecho divino en las celebraciones reales de la América borbónica», Revista de Historia del Derecho, 34, 2006, 241-267.

Rodríguez-Salgado, María José: Un Imperio en transición. Carlos V, Felipe II y su mundo, Barcelona, Crítica, 1992.

Romero Tallafigo, Manuel: «Las ceremonias de recepción del Documento Real en los cabildos municipales del Antiguo Régimen», en García Bernal, Manuela Cristina y Olivero Guidobono, Sandra (coords.), El municipio indiano: relaciones interétnicas, económicas y sociales. Homenaje a Luis Navarro García, Sevilla, Universidad de Sevilla, 2009, 445-460.

Romero Tallafigo, Manuel: «Simbología retórica y visual del diploma y del documento de archivo del Medieval al Contemporáneo», en Rey de las Peñas, Remedios (coord.), Actualidad de la heráldica y la sigilografía: Quintas Jornadas Archivísticas, Huelva, Diputación de Huelva, 2000, 163-232.

Ruiz García, Elisa: «El poder de la escritura y la escritura del poder», en Nieto Soria, José Manuel (dir.), Orígenes de la Monarquía hispánica: propaganda y legitimación (1400-1520), Madrid, Dykinson, 1999, 276- 313.

Sánchez Arcilla Bernal, José: Instituciones Político Administrativas de la América Hispánica, Madrid, Universidad Complutense, 1999.

Sanz Camañes, Porfirio: Las ciudades en la América hispana: siglos XV al XVIII, Madrid, Silex Ediciones, 2004.

Torre Molina, María: Música y ceremonial en las fiestas reales de proclamación de España e Hispanoamérica (1746-1814), Granada, Universidad de Granada, 2004.

Vaca de Osma, José Antonio: Carlos I Y Felipe II, Frente a Frente: Glorias, Mitos Y Fracasos de dos grandes reinados, Madrid, Rialp, 1998.

Val Valdieso, María Isabel: «Las fiestas en la Primera Década de Alonso de Palencia», en La Península en la Edad Media. Treinta años después. Estudios dedicados a José Luis Martín, Salamanca, Ediciones Universidad de Salamanca, 2006, 371-387.

Valenzuela Márquez, Jaime: «Rituales y fetiches políticos en Chile colonial: entre el sello de la audiencia y el pendón del cabildo», Anuario de Estudios Americanos, 56-2, 1999, 413-440. 
Valenzuela Márquez, Jaime: Las Liturgias del Poder. Celebraciones públicas y estrategias persuasivas en Chile colonial (1609-1709), Santiago de Chile, Dirección de Bibliotecas, Archivos y Museos, 2001.

Vilaplana Persiva, Manuel: Historia del real de a ocho, Murcia, Universidad de Murcia, 1997.

Vincent, Bernard: «La Iglesia y los toros», en García-Vaquero González, Antonio y Romero de Solís, Pedro (eds.), Fiestas de toros y sociedad, Sevilla, Secretariado de Publicaciones de la Universidad, 2003, 337-353.

VV.AA.: Historia de América Andina. Vol. 2: Formación y apogeo del sistema colonial (Siglos XVI-XVII), Manuel Burga (ed.), Quito, Universidad Andina Simón Bolívar, 2000. 


\title{
Anexo documental
}

\author{
1557, diciembre, 10. Cuzco \\ El cabildo de Cuzco reconoce a Felipe II como rey, presta juramento de leal- \\ tad y celebra su coronación. \\ AGI. Lima 110, doc. 21. Papel. Buen estado de conservación. Escritura \\ redondilla.
}

\section{Sacra Católica Real Magestad}

Puesto que en nuestros coraçones, desde que Dios nos dio a vuestra Magestad por príncipe, sienpre os avemos tenido por Rey y señor, conociendo que a sido tan grande merçed la que nuestro Señor nos ha echo en suçeder tal hijo a tal padre como en abernos guardado hasta aquí la ymperial persona, debajo de cuya mano y anparo estos reynos an ydo en tanto acreçentamiento.

Vista la carta de la magestad ynperial y la real vuestra con otra que el marqués de Cañete, vuestro bisorrey, nos escreuió, el liçençiado Baptista Muñoz vuestro corregidor, en vuestro real nonbre con su estandarte en las manos y esta çiudad con el suyo, alçándolos con grande alegría y haziendo las demás çirimonias en semejante acto necesarias, con alegre obedençia y leales coraçones apellidamos vuestro real nombre, llamando y publicando por nuestro rey y señor a don Felipe, rey de Castilla y de León y de los estados de las Yndias y de Yngalatierra y Françia y por tal todos, con vna voz y un coraçón, diximos que ansí lo reçeuíamos y por tal real magestad os reçevimos y tenemos y reconoçemos y obedeçemos y acataremos y seruiremos y biuiremos y moriremos en vuestro real servicio, porque demás de que como leales vasallos os lo deuemos como a señor nuestro natural, nos obliga a ello vuestra alta bondad y humanidad que en la que a esta vuestra çiudad del Cuzco hizistes merçed de mandar escreuir mostrais, plega a nuestro Señor que Vuestra Magestad goze del real ceptro por largos años con la feliçidad que el que os lo dexó tan ensalçado os desea para que se acreçiente en vuestra real persona lo que resta de la monarquía del mundo. Y se entienda y conozca en todo el que de tal padre sino el que lo es. Según la obligaçion que da a Vuestra Magestad de seguir y lleuar adelante tan heróicos y esclareçidos hechos que están començados, non es menor la carga que tomáis a vuestros honbros que la ventura que tuvisteis para suceder en ellos y ansí no será menor la virtud y grandeza de vuestro real ánimo para los acavar. Y estamos çiertos que pues vuestra Magestad real en todo ymitará la ymperial de su padre, no lo hará menos en las merçedes que siempre hizo a estos reynos para que se avmenten, fauorezcan y ensanchen, pues las cosas y contrataçiones de ellos por su $/ /^{1 \mathrm{v}}$ dificultad, ansí por mar como por tierra, an menester toda la merçed y fauor que se les hiziese para que no çese el remedio de ellos. 
Y vna de las mas señaladas que se les podría hazer y reçeuirán por tal es que mandásedes a vuestro visorrey, el marqués de Cañete, que se perpetuase en estos reynos, trayendo a ellos a la marquesa, su muger, porque según entendemos de su prudençia, christiandad, virtud y buen gouierno y vemos la quietud y paz que con su benida a puesto en ellos, lo que otro ninguno a podido ni açertado a hazer, lastimados de las desbenturas pasadas, y biendo el remedio que Dios y Vuestra Magestad enbiaron a este reyno, deseamos afirmarle por todas vías por lo que conbiene a Vuestro Real seruiçio y a la quietud general de la tierra y acreçentamiento de ella y para los que en ella beuimos, osemos alegremente y sin reçelo trocar por ella nuestras propias naturalezas, y ansí suplicamos a Vuestra Magestad se lo mande y con breuedad para que çesen las calamidades que asta aquí a abido, como de todo abrá dado quenta don Antonio de Riuera a quien para este efecto y para besar vuestros reales pies estos reynos enbiaron en el tienpo que Françisco Hernandez Girón y sus çecazes se rebelaron contra Vuestra real corona, como ya lo abrá hecho. El cual, ansí mesmo, llevó por ynstruçión, entre las otras cosas, que suplicase a Vuestra Magestad por la perpetuydad de las encomiendas de yndios, que tanto conbienen para la conservación de ellos y para el sosiego de la tierra y para el remedio de todos los que aca están, que con los travajos pasados quedan fatigados, desechos y alcançados de los gastos y derramamientos de sangre que en Vuestro real seruiçio an echo, que en largos años de otra manera no tornarán sobre sí.

Y porque en esto y en todo entendemos que Vuestra Magestad nos abrá echo la merçed y remetídolo a vuestro bisorrey para que en vuestro real nonbre por su mano lo haga, pues ninguno otro lo podrá entender ni açertar como él como quien tanbién a entendido la tierra y el remedio de ella y los méritos de los que os an seruido, çesamos suplicando a Nuestro Señor la Sacra Católica Real Persona de Vuestra Magestad guarde con reconoçimiento del huniuerso como nosotros, vuestros humildes vasallos, lo deseamos.

Del Cuzco, a diez de deciembre de mill e quinientos y çinquenta y siete años. Sacra Cesárea Católica Magestad

Vuestros humildes vasallos, que vuestros reales pies vesan.

El liçençiado Muñoz (rúbrica). Diego Ortiz de Guzmán (rúbrica). Alonso de Loaysa (rúbrica). Juan Julio de Oxeda (rúbrica). Pero López (rúbrica). Fabián de la Torre (rúbrica). //2r Jerónimo Costilla (rúbrica). Rodrigo De Esquivel (rúbrica).

Por mandado de la çibdad de Cuzco, Sancho de Orúe, escribano (rúbrica).//

En la gran çiudad del Cuzco, cabeça de los reynos e probinçias del Perú de las Yndias del mar océano, miércoles, día de la benditísima Conçepción de la madre de Dios, ocho días andados del mes de dizienbre, año del nasçimiento de nuestro Salbador Iesu Christo de mill y quinientos y çinquenta y siete años. A las siete oras de la mañana, en la plaça pública de la dicha ciudad, junto a la yglesia 
catedral de ella, que es la advocaçión la Asunçión de Nuestra Señora. Y estando echo un cadalso de madera cubierto y avtorizado y puestos en él los retratos y figura del Enperador y Rey don Carlos, quinto de este nombre, nuestro señor, y de la Magestad del Rey don Felipe, su hijo. Presentes junto al dicho cadahalso el muy magnífico señor, el liçençiado Baptista Muñoz, corregidor y justiçia mayor en la dicha çiudad del Cuzco, nonbrado por el muy eçelente señor marqués de Cañete, guarda mayor de la çiudad de Cuenca en los reynos de España, visorrey y capitán general en los dichos reynos y probinçias del Pirú por su Magestad, etc., bestido con vna ropa rozagante de raso morado, guarneçida de terçiopelo morado, y vna gorra de terçiopelo morado tocado; y el ilustre y reberendísimo señor don Juan Solano, obispo de la Sancta Yglesia de la dicha çiudad, del Consejo de su Magestad; estando presentes los señores consejo y justiçia y regimiento de la dicha çiudad del Cuzco, conbiene a saber: Diego Hortiz de Guzmán y Alonso de Loaysa, alcaldes hordinarios en ella por su Magestad, y Juan Julio de Ojeda y Pero López de Caçalla y Martín Hurtado de Harbieto y Fabián de la Torre y Gerónimo Costilla y Juan de Pancorbo y Rodrigo de Esquibel, regidores de la dicha çiudad, y Manso Sierra, procurador general de ella; yo, Sancho de Orúe, escriuano del dicho ayuntamiento, y Miguel Sánchez, mayordomo; todos los dichos señores y justiçia y regimiento bestidos de ropas roçagantes de raso y damasco morado, guarneçidas en terçiopelo de la mesma color, con gorras de lo mesmo ricamente adreçadas; estando, ansí mesmo, presentes el tesorero Garçía de Melo y Andrés de Villarreal, fator y behedor, y Françisco Çapa-//3v-tán, contador, ofiçiales de la Real Hazienda de la dicha çiudad del Cuzco, vestidos con ropas françesas de terçiopelo azul, guarnecidos con pasamanos de oro y gorras y plumas de la mesma color, todos en buenos cavallos y ricos jaezes; estando, ansí mesmo, presentes con el dicho señor obispo, el deán y cavildo de la dicha sancta Yglesia, conbiene a saber: el deán, don Françisco Ximénez, y el chantre don Hernán Darias y el maestre esqüela, don Diego Flores, y don Juan de Gallegos, tesorero, y el canónigo Albar Alonso y el canónigo Juan de Cuéllar, benefiçiados y canónigos en la dicha Sancta Yglesia, y Alonso de Hinao, cura, y Pero Caro y Martín Harias, capelanes en ella, todos los dichos señores deán y cauildo, cura y capelanes, cavalleros en sus mulas y bestidos de ropas largas de raso y damasco carrmesí y grana fina, con becas de terçiopelo carmesí y bonetes de grana.

Y estando, ansí mesmo, congregados otros muchos caualleros y çiudadanos estantes y residentes en la dicha ciudad, que para el presente acto se juntaron delante del dicho cadahalso y retratos, y estando el dicho señor corregidor a cavallo rucio, rodado, adreçado a la brida y teniendo en su porta clave vn estandarte real de damasco carmesí bordadas en él las armas reales en la una banda y en la otra; y, ansí mismo, Juan Julio de Ojeda, regidor de la dicha ciudad, en un cavallo rosillo, caueça de moro y adreçado a la brida y en un porta clave otro estandarte y pendón de damasco blanco, figurado en él de la una banda la ymagen del glorioso 
apóstol Santiago, patrón de España, y de la otra, las armas de la dicha çiudad del Cuzco; y estando delante de los dichos señores corregidor y obispo y cauildos quatro porteros de la dicha çiudad a cavallo, bestidos de damasco berde con gorras y calças de la $/ /^{4 \mathrm{r}}$ mesma color los dos de ellos con dos maças y los otros dos con dos bastones a los honbros y muchas tronpetas bestidas de tafatanes hazules y amarillos con las armas de la dicha çiudad, con música de atabales, bestidos y adereçados de las sedas y colores de las dichas trompetas.

$\mathrm{Y}$ auiendo tocado buena cantidad de tienpo los dichos atabales y trompetas, haviendo parado, en silençio el dicho señor corregidor tomó en las manos vna carta que pareçía ser del Enperador don Carlos, nuestro Rey y señor, e la besó y puso sobre su caueça y la dio a mí el dicho escriuano del dicho cauildo, y me la mandó ler de manera que los sircustantes la pudiesen hoir y entender, la qual yo reçeví. Y echo el mesmo acatamiento en cunplimiento de lo que por el dicho señor corregidor mandado, la ley en claras e ynteligibles bozes, la qual es del tenor siguiente:

El sobreescrito dezía: por el Rey. Al Concejo, justiçia y regidores de la çiudad del Cuzco de las probinçias del Pirú. Dentro dezía:

\section{El rey.}

Concejo, justiçia y regidores caualleros, escuderos, ofiçiales y omes buenos de la çiudad del Cuzco. Ya tenéys entendido el suceso que han tenido nuestras cosas y como enprendí la guerra en Alemania por lo tocante a la religion deseando como hera razón por la obligaçión que tenía a reduzillos y boluerlos al gremio de la Yglesia, procurando de poner paz y quietud en la Christiandad, asistiendo y haziendo por mi parte todo lo posible para que se conbocase el conçilio, procurando que se concluyese, haziendo la reformaçión tan necesaria por mejor atraer a los que se an apartado y desbiado de la fee, y teniéndolo por la bondad de Dios en buenos términos el rey de Francia ronpió húltimamente la guerra por mar y tierra sin tener ninguna justa causa ni fun- $/ /^{4 \mathrm{v}}$ damento, ayundándose de los alemanes que contra su fielidad hizieron liga con él y trayendo la harmada del turco con tanto daño de la Christiandad y espeçialmente de nuestros estados y señoríos queriéndolos ynbadir. De manera que por lo vno y lo otro fuy forçado y neçeçitado a leuantar los exérçitos que ha juntado, de que se me an seguido grandes trauajos, ansí por aver estado en canpaña como por tratar negoçios tan contínuos y pesados que se an ofreçido, que an sido causa de la mayor parte de las enfermedades e yndispusiçiones tan largas que he tubido y tengo de algunos años a esta parte, de allarme tan ynpidido y falto de salud que no sólo los he podido ni puedo tratar por mi persona y con la breuedad que conbernía, mas conozco que ha sido ynpedimento para ello de que he tenido y tengo escrúpulo y quisiera mucho aver antes de hagora dado horden en ello. Pero por algunas sufiçientes causas no se ha podido hazer en ausençia del serenísimo rey de Yngalatierra y Nápoles, prínçipe de España y nuestro muy caro e muy amado hijo, por ser menester comunicar, asentar y tratar con él 
cosas ynportantes y para este propósito demás de venir a efetuar su casamiento con la serenisima reyna de Yngalatierra y le hordené que pasase húltimamente en esas partes; y abiendo benido aquí, acordé, como de prinçipio lo tenía determinado, renunçiarle, çederle y traspasarle desde luego, como lo he echo los reynos e señoríos y estados de la corona de Castilla y León y lo anexo y dependiente a ellos, en que se yncluien esos estados de las Yndias, como más cunplida y bastantemente se contiene y declara en la escritura que de esto hizimos y otorgamos en la villa de Bruselas, a diez y seis días del mes de henero deste presente año de mill e quinientos y çinquenta $/ /{ }^{\text {rr }}$ y seis años, confiando que con su mucha prudençia y esperiençia segund lo a mostrado hasta aquí en todo lo que a tratado en mi lugar y nonbre y por sí propio los governará, administrará, defenderá y terná en paz e justiçia.

Y siendo çierto que vosotros siguiendo vuestra lealtad y el amor que a mí y a él avéis tenido y tenéis, como lo avemos conoçido por obra, le siruiréys como lo confío y debéys a la voluntad que anbos os auemos tenido y tenemos, e ansí os encargamos y mandamos que, alçando pendones y haziendo las otras solenidades que se requieren y acostunbran para la execuçión de lo sobredicho de la misma manera que si Dios obiese dispuesto de mí, obedescáys y sirváis, acatéis y respetéis al dicho serenísimo Rey, cunpliendo sus mandamientos por escrito y de palabra daquí adelante como de vuestro berdadero señor y rey natural, segund y como avéis cunplido y debíades cunplir los míos propios, que demás de hazer lo que soys obligado, me terné en ello por muy seruido.

De Bruselas, a XVI días del mes de henero de mill e quinientos e çinquenta $\mathrm{y}$ seis años.

Yo, el Rey.

Por mandado de su Magestad, Françisco de Eraso.

Y ansí leyda la dicha carta, luego ynconteniente el dicho señor corregidor tomó otra carta, que pareçía ser de la Magestad del serenísimo príncipe don Felipe, Rey de Yngalatierra, y la besó y puso sobre su cabeça y la dio y entregó a mí, el dicho Sancho de Orúe, escriuano, para que la leyese, la cual yo receuí y echo el mesmo acatamiento la ley como la de la magestad ynperial, la qual es del tenor siguiente:

Dezía en el sobreescrito: Por el Rey. Al concejo, justiçia, regidores de la ciudad del Cuzco, de las prouiençias del Pirú.

Dentro dezía:

El Rey.

Conçejo, justiçias, regidores, caballeros, escuderos, ofiçiales, y omes buenos de la çiudad del Cuzco de las provinçias del Pirú. Por la carta que el Enperador Rey, mi señor, os escriue veréys la determinación $/ /^{\text {sv }}$ y resoluçión que a tomado en renunciar, çeder y traspasar en mí los reynos y señoríos de la corona de Castilla y 
León y lo anexo y dependiente a ellos, en que se yncluyen esos Estados de las Yndias, de que ha otorgado las escrituras neçesarias en forma. Y e sentido en el grado que es razón hallar a su Magestad, tan ynpedido y falto de salud por sus muchas y continuas enfermedades, que por su persona no pueda tratar ni entender en la expidiçión de tantos y tan graues negoçios como cada día se ofreçen por la grandeza de sus estados y estar tan diuididos y separados porque con su larga espirinçia y prudençia lo pudiera mucho mejor hazer, pero conformándome con su voluntad lo he açeptado confiando en Dios, nuestro Señor, me dará fuerças para administrar bien lo que su Magestad me ha encargado, alibiándole de tantos trauajos y cuydados para que más libremente atienda al descargo de su conçiençia y a la conseruaçión de su salud, que se la deseo como la propia mía.

Y siendo cierto, pornéis luego en execuçión lo que su Magestad cerca desto provee y hordena, no me queda que dezir sino çertificaros que acordándome de vuestra fidelidad y lealtad y del amor y afiçión espeçial que entre vosotros he conoçido, mandaré mirar por lo que general y particularmente os tocare, haziéndoos merçed y fauor en lo que justo sea como lo mereçéyes y ansí confío que en lo que ocurriere me servireyes y ayudareyes, como lo aveys mostrado por la obra en lo que se ha ofreçido, y sobre todo, tener el cuydado que es razón de que seáys bien gouernados y mantenidos en paz y en justiçia.

De Bruselas, a XVII días del mes de henero de mill e quinientos e çinquenta y seys años.

Yo, el Rey.

Por mandado de Su Magestad, Françisco de Eraso.

Y así leydas las dichas dos cartas, el dicho señor corregidor y justiçia mayor dixo a altas vozes: «escriuano presente dad por testimonio como yo, como corregidor y justiçia mayor desta grand çiudad del $/ /{ }^{\text {r }}$ Cuzco por su Magestad y como su criado y basallo de don Felipe, príncipe de España y rey de Yngalatierra, y en su real nombre, tomo y apreendo la tenencia y posesion desta dicha çiudad y provincia.»

Y luego, en continente, el dicho cauildo, justiçia y regimiento dixo a mí el dicho escriuano, que le diese por testimonio cómo receuían por su rey y señor natural al dicho señor rey don Felipe y que estauan prestos de obedecer y cunplir sus prouisiones reales, bien así como lo mandan por sus reales cartas, y biuir y morir en su real servicio, como sus leales vasallos.

Y echo lo susodicho, el dicho señor corregidor y justiçia mayor, teniendo delante de sí una fuente grande de oro y en ella cantidad de monedas de oro y plata, figurado en ellas las armas y marca real, dio de ella çierta cantidad al dicho señor obispo para que lo derramase, el qual y el dicho señor corregidor derramaron las restantes en señal del la dicha poseçión y manejó el cauallo en que estaua con el dicho estandarte real diciendo: «Castilla, Castilla; Cuzco, Cuzco; Perú, 
Perú, por el Rey don Felipe, nuestro señor». Y tras él, el dicho Juan Julio con el estandarte y Armas de la dicha çiudad, publicando y diziendo a altas vozes: «Castilla, Castilla; Cuzco, Cuzco; Perú, Perú, por el Rey don Felipe, nuestro señor».

Y luego, el dicho cauildo, caualleros, vezinos y ciudadanos, residentes y estantes en la dicha çiudad, congregados, siguiendo al dicho señor corregidor alderedor del dicho cadahalso corrieron en sus cauallos con mucho regozijo con la dicha música de atauales y trompetas, diziendo y apelidando a altas bozes: «Castilla, Castilla; Cuzco, Cuzco; Perú, Perú, por el Rey don Felipe, nuestro señor».

Y abiendo buen espacio de tiempo, echas las dichas alegrías y regoçijos, en silençio, //6v se cantó música de cantores, muchos motes y coplas manifestando el alegría de la subçión del dicho rey don Felipe, nuestro señor, principiando y acauando todos los dichos motes y coplas en una que dezía:

«Venga en nora buena

En nora buena venga

El rey don Felipe

A la nueba tierra».

Y acabada la dicha música, el dicho señor corregidor y obispo y cauildos, todos juntos y concurso de gente fueron por la dicha çiudad del Cuzco y calles de ella apellidando por las esquinas: «Castilla, Castilla; Cuzco, Cuzco; Perú, Perú, por el Rey don Felipe, nuestro señor», muchas y diversas bezes. Y manejando los cauallos con los dichos estandartes y aviendo andado por la mayor parte de la dicha çiudad y se fueron a apear a las gradas de la dicha yglesia catredal, a donde entraron. Y el dicho señor obispo, bestido de pontifical, abiéndose echo proçesión, con grande solenidad frayles de las hórdenes de sancto Domingo y san Françisco y Nuestra Señora de la Merçed y espeçialmente fray Juan de Aguilera, comisario general de la dicha horden de san Françisco, y fray Juan de Bargas, probinçial de la de Nuestra Señora de la Merçed. El dicho señor obispo dixo la misa de la fiesta, aviendo sermón en ella de fray Antonio de San Miguel, guardián de la casa del señor San Françisco de la dicha ciudad.

Y aviéndose dicho la dicha misa, el dicho señor corregidor y justiçia mayor tornó a tomar el dicho estandarte Real en sus manos y el dicho Juan Julio de Ojeda el dicho estandarte y pendón de la dicha çiudad y juntamente con el dicho señor obispo y cauildos tornaron a salir de la dicha iglesia. E caualleros en sus cauallos y mulas fueron a la posada del dicho señor corregidor, que es la casa que su Magestad tiene en la dicha ciudad, donde dexaron el dicho estandarte real y el dicho estandarte y pendón.

Lo qual $/ /^{7 r}$ presençia de mí, el dicho Sancho de Orúe, escriuano que a todo lo que dicho es e sido presente. 
Los dichos señores corregidor y justiçia mayor, obispo y cauildos hizieron ansí como está dicho y declarado, en cunplimiento de la renunçiaçión referida en la dicha carta ynperial y lo que por ella el dicho enperador, don Carlos nuestro señor les manda y en cumplimiento, ansí mesmo, de la aceptaçión de estos reynos del Pirú contenida en la carta del dicho serenísimo rey don Felipe nuestro rey y señor natural, a quien todos, por la horden arriba declarada y con las dichas cirimonias y solenidades reçevieron, açeptaron por tal rey y señor natural suyo, a quien Dios, nuestro Señor, guarde por largos tienpos y prospere con reconoçimiento de la hunibersal monarquía y como a tal le ofreçieron y dieron la obediencia, ofreçiéndose a le seruir, tener y respetar como leales y buenos vasallos suyos, en todo y por todo, segund y de la manera que/ por las dichas cartas les hes mandado.

Siendo testigos a ello presentes: Antonio de Quiñones, Garcilaso de la Vega, Alonso Álbarez de Hinojosa, Diego de los Ríos, Hernán Brauo de Lagunas, e otros muchos vecinos y estantes en esta dicha ciudad.

Después de lo cual, el dicho día, aviendo sido mandado por el dicho señor corregidor e justiçia mayor e cabildo que oviese regozijo de toros e juegos de cañas en la plaça, donde se acostumbran hazer semejantes fiestas, fueron traídos y corridos treynta toros en la dicha plaça, en continuando las dichas fiestas. E aviendo sido librados los dichos toros, a la tarde salieron con mucha música de atabales y trompetas dos puestos de caualleros jugadores de cañas el vno de los quales se le encomendó a Antonio de Quiñones y el otro, al dicho Juan Jullio de Hojeda, alférez, con ricas libreas, todas de sedas, en ocho cuadrillas, en lo qual salieron las personas siguientes: Antonio de Quiñones, Gerónimo Costilla, Diego de los Ríos, Ihoan de Pancorbo, Juan de Çelórigo, su hijo, Antonio Marchena, Don Carlos Yupangui, yndio, Ihoan de Salas de Valdés, Gaspar de Sotelo, Gómez Xuárez de Figueroa, hijo de Garçilaso de la Vega, Pedro de Orúe, Juan de la Plaça, Juan López de Yzturiçaga, Ihoan Julio de Hojeda, Gómez de Tordoya, su cuñado, Garçía //7v de Cabrera en lugar de Rodrigo Desquivel por traer luto, Alonso Álbarez de Hinojosa, Mançio Serra, Diego de Vargas, que salió en lugar de Pero López de Caçalla, su cuñado, por estar enfermo de la gota, Alonso de Loaisa, Martín de Meneses, Ordoño de Valençia, Fabián de la Torre, alguacil mayor, y el contador Françisco Çapata, Miguel Sánchez. Y auiendo jugado y escaramuçado con mucha horden e conçierto se acabaron las dichas fiestas.

E yo, Sancho de Orúe, escribano de su Magestad, del número y cabildo desta dicha çiudad del Cuzco, fuy presente a todo lo susodicho y pasó ante mi e doy fee de ello e fago aquí este myo sygno que es a tal (signo) en testimonio de verdad. Sancho de Orúe, escribano público (rúbrica).

Gratis. 